Justyna Skóra ${ }^{1}$

http://dx.doi.org/10.13075/mp.5893.2014.005

\author{
Beata Gutarowska ${ }^{1}$ \\ Łukasz Stępieńn \\ Anna Otlewska ${ }^{1}$ \\ Katarzyna Pielech-Przybylska ${ }^{1}$
}

\title{
THE EVALUATION OF MICROBIAL CONTAMINATION IN THE WORKING ENVIRONMENT OF TANNERIES
}

\section{OCENA ZANIECZYSZCZENIA MIKROBIOLOGICZNEGO NA STANOWISKACH PRACY W GARBARNIACH}

\author{
${ }^{1}$ Lodz University of Technology / Politechnika Łódzka, Łódź, Poland \\ Institute of Fermentation Technology and Microbiology / Instytut Technologii Fermentacji i Mikrobiologii \\ ${ }^{2}$ Institute of Plant Genetics of the Polish Academy of Sciences / Instytut Genetyki Roślin Polskiej Akademii Nauk, Poznań, Poland
}

\begin{abstract}
Background: Due to their animal material processing, tannery workers may be exposed to biological agents. The aim of the study was the microbial contamination assessment of tanneries with different production specifications. Health risk was estimated based on particle size distribution. Moreover, indicators of microbial contamination of tanneries were selected. Materials and Methods: The studies were conducted in 2 types of tanneries - processing raw hides and producing chrome-tanned leather. Air was sampled with MAS-100 Eco Air Sampler, leathers using RODAC Envirocheck ${ }^{\circledR}$ contact plates and swab method, microbial numbers were determined by a culture method. For the bioaerosols size distribution analysis, a six-stage Andersen sampler was used; identification was performed using microscopy and biochemical methods. Microbial contamination was identified by $16 \mathrm{~S}$ RNA and ITS1/2 rDNA analysis for bacteria and fungi respectively. Results: The microbial number in the air ranged between $1.2 \times 10^{3}$ and $3.7 \times 10^{3} \mathrm{CFU} / \mathrm{m}^{3}$. While on the leather, it ranged between $7.6 \times 10^{1}$ and $5.5 \times 10^{5} \mathrm{CFU} / 100 \mathrm{~cm}^{2}$. Bacteria dominated in the tanneries (air: $51-92 \%$, leathers: $60-100 \%$ ). Results indicate that potential health risks arise from the fungal small bioaerosol particles presence $(0.65-2.1 \mu \mathrm{m})$. Eleven indicator microorganisms were determined: B. pumilus, B. subtilis, B. cereus, C. lubricantis, C. cladosporioides, $P$. commune, $P$. echinulatum, $P$. chrysogenum, $P$. crustosum C. parapsilosis and C. albidus. Conclusions: Microbial contamination evaluation in the tanneries showed the increased bacteria and fungi number in the air in relation to the outdoor air, which indicates an occupational inhalation risk to workers. The designated indicators of microbial contamination in the tanneries are associated with their specific and potentially pathogenic working environment. Med Pr 2014;65(1):15-32
\end{abstract}

Key words: tanneries, bioaerosols, microbial contamination, microbial indicators

\section{STRESZCZENIE}

Wstęp: Z powodu przetwarzania surowca zwierzęcego w garbarniach pracownicy mogą być narażeni na czynniki biologiczne. Celem badań była ocena zanieczyszczenia mikrobiologicznego w garbarniach o różnej specyfice produkcji. Określono także ryzyko zdrowotne w oparciu o rozkład ziarninowy bioaerozolu. Ponadto wyznaczono wskaźniki zanieczyszczenia mikrobiologicznego w garbarniach. Materiał i metody: Badania przeprowadzono w dwóch rodzajach garbarni - przetwarzających skóry surowe i chromowo garbowane (wet blue). Powietrze pobierano próbnikiem MAS-100 Eco, próby ze skór, używając płytek odciskowych RODAC Envirocheck i metody tamponowej, a liczbę mikroorganizmów określano metodą hodowlaną. Rozkład cząstek biooaerozolu wykonano z użyciem 6-stopniowego impaktora Andersena. Identyfikację drobnoustrojów wykonano metodą mikroskopową i testami biochemicznymi. Wskaźniki zanieczyszczenia mikrobiologicznego identyfikowano, analizując odpowiednio dla bakterii i grzybów sekwencje 16S RNA i ITS1/2 rDNA. Wyniki: Liczebność mikroorganizmów w powietrzu w garbarniach kształtowała się w granicach $1,2 \times 10^{3}-3,7 \times 10^{3} \mathrm{jtk} / \mathrm{m}^{3}$. Skóry były zanieczyszczone mikrobiologicznie w granicach $7,6 \times 10^{1}-5,5 \times 10^{5} \mathrm{jtk} / 100 \mathrm{~cm}^{2}$. W garbarniach dominowały liczbowo bakterie (w powietrzu: 51-92\%, na skórach: 60-100\%). Wskazano na zagrożenie zdrowotne wynikające z obecności cząstek bioaerozolu grzybowego o rozmiarach 0,65-2,1 $\mu \mathrm{m}$. Wyznaczono 11 gatunków drobnoustrojów wskaźnikowych dla garbarni: B. pumilus, B. subtilis, B. cereus, C. lubricantis, C. cladosporioides, P. commune, P. echinulatum, P. chrysogenum, P. crustosum, C. parapsilosis i C. albidus. Wnioski: Ocena zanieczyszczenia mikrobiologicznego w garbarniach wykazała podwyższoną liczebność bakterii i grzybów w powietrzu w stosunku do powietrza atmosferycznego, co świadczy o występowaniu narażenia inhalacyjnego pracowników. Wyznaczone wskaźniki zanieczyszczenia mikrobiologicznego w garbarni są związane ze specyfiką środowiska pracy i potencjalnie chorobotwórcze. Med. Pr. 2014;65(1):15-32

Słowa kluczowe: garbarnia, bioaerozol, zanieczyszczenie mikrobiologiczne, wskaźniki mikrobiologiczne

Corresponding author / Autorka do korespondencji: Justyna Skóra, Institute of Fermentation Technology and Microbiology, Lodz University of Technology, Wólczańska 171/173, 90-924 Łódź, Poland, e-mail: justyna-skora@wp.pl

Received: 2013, October 15, accepted: 2014, January 3

Studies were realized within the project of Polish National Center for Research and Development coordinated by the Central Institute for Labour Protection - National Research Institute, no. III.B.03 entitled "Development of principles for evaluation and prevention of hazards caused by biological agents in the working environment using indicators of microbial contamination”. 


\section{INTRODUCTION}

Leather is an important raw material used in the manufacture of footwear, apparel, furniture and leather products. In 2011, the total turnover of the European Union tanning industry reached 7.8 billion euro, corresponding to the production of 224 million $\mathrm{m}^{2}$ of finished leather and about 44 thousand tons of sole leather. Currently, it is estimated that leather product industries in the European Union have about 24000 of different-sized enterprises employing a total of 400000 workers (1).

In order to give the leather adequate durability and aesthetic quality, it is necessary to perform a series of mechanical and chemical operations, wet and finishing processes $(2,3)$. These treatments are necessary because fresh animal skins are of limited value, as they contain large amounts of moist and available nutrients (carbohydrates, fats and proteins) that provide a perfect medium for rapid growth of microorganisms (4). The sources of microorganisms are diverse. The skin may be contaminated with blood, feces or soil; the means of transport, air and equipment in production and storage facilities should be also considered. Bacteria that are most often isolated from raw hides belong to the species: Escherichia coli, Staphylococcus epidermidis, Proteus mirabilis, Morganella morganii, P. morgani, P. vulgaris, Bacillus anthracis, B. subtilis and $B$. mycoides $(4,5)$. The action of bacterial proteolytic enzymes results in partial or complete hydrolysis of leather components, the emission of ammonia and hydrogen sulphide, stains and damage to the leathers surface $(6,7)$.

Leather has a higher biological resistance than raw hide. This is because it contains collagen, which is resistant to proteolytic enzymes (except collagenase) and a small amount of water (preferably due to the functional characteristics $14-20 \%)(8)$. Microbiological destruction of chrome-tanned leather (wet blue) and leather results mainly from the activity of filamentous fungi (9). The studies of microbial contamination of leather have shown that the dominant species are filamentous fungi from the genera Penicillium (P. commune, $P$. glaucum, $P$. wortmannii, P. frequentans) and Aspergillus (A. niger, A. flavus, A. oryzae, A. fumigatus). Apart from those, the occurrence of the species from the genera: Alternaria, Cladosporium, Trichoderma, Fusarium, Aureobasidium, Scopullariopsis and also actinomycetes from the genus Streptomyces was observed on the surface of tanned hides (10). They can cause a breakdown of fat and loosening of hide fibres, and create differently coloured stains $(11,12)$. The growth of microorganisms in raw hides, chrome-tanned leather and finished products may pose a threat to tanners, especially those involved in the first operations of tanning. Potential microbiological hazards in the working environment of tanneries may result from the exposure to high concentrations of pathogens in raw material and in the air of production facilities as well as from the contact with pathogens. Pathogenic microorganisms found in the working environment include: Bacillus anthracis (anthrax), Leptospira interrogans (leptospirosis), Clostridium tetani (tetanus), Coxiella ( $\mathrm{Q}$ fever) and Brucella melitensis, B. suis, B. abortus and B. canis (brucellosis) (13).

There have been reports concerning various health problems among workers in tanneries. In the study carried out by Ory et al. (14) the health complaints among 418 labourers in 15 Indian tanneries were tested. Asthma (38\%), dermatitis (23\%) and chronic bronchitis (14\%) were the most frequently reported complaints in the 12 months prior to the survey. Moreover, $\mathrm{Cr}^{6+}$ ions cause skin irritation, eardrum perforation, nasal irritation, ulceration and lung carcinoma in humans and animals, and are accumulated in placenta impairing the foetal development in mammals (14). Rastogi et al. (15) analysed the health risks of 197 male workers drawn from different sections of 10 leather tanneries in Kanpur. A control group comprising of 117 male subjects belonging to a similar age group and socioeconomic strata, who never had any occupational exposure in the leather tanneries, were also examined for comparison. The findings revealed a significantly higher prevalence of morbidity among the exposed workers in contrast to that observed in the controls ( $40.1 \%$ vs. $19.6 \%)$.

Respiratory diseases (16.7\%) were mainly responsible for a higher morbidity among the exposed workers, whereas gastrointestinal tract problems were predominant in the control group (15). There has only been a limited number of studies on the microbiological risks in the working environment of tanneries. The aim of the present studies was to analyse the degree of microbial contamination and the type of microorganisms in the working environment of tanneries with different production specifications - those processing raw hides and those producing wet blue leather. Health risk was also estimated basing on a study of particle size distribution in a selected facility. 
Moreover, indicator microorganisms were selected for the working environments of the tanneries basing on an analysis of their prevalence in a workplace, source of isolation, and health risk determined based on literature data (according to the classification of the Directive 2000/54/EC (16)), the Regulation of the Minister of Health in Poland dated 22nd of April, 2005 (17), the biosafety levels classification (BSL) of the European Confederation of Medical Mycology (18) and the Institute of Rural Health in Lublin (Instytut Medycyny Wsi im. Witolda Chodźki w Lublinie) (13). The taxonomic classification of the selected indicators was confirmed using molecular methods.

\section{MATERIAL AND METHODS}

\section{Description of the studied rooms}

The assessment of microbial contamination was performed in 4 tanneries with different production specifications. Two of the studied tanneries (Tanneries I and II) produced wet blue leather, and the production process was mainly based on retanning, dyeing and finishing leather. The 2 other plants (Tanneries III and IV) specialized in the production of leather for shoes and fancy goods; the production process included all stages of raw hide (fresh and salted) processing and ended up obtaining leather for the production of leather goods.

Description of the tested rooms is given in Table 1. Temperature and humidity in the tested rooms were determined using a PWT-401 hygrometer (Elmetron, Poland). Samples of the air were also taken in an office room (internal background) and in the atmospheric air (external background).

\section{Determination of microbiological contamination of the air and leathers}

Samples for the analysis of microbial contamination of the air and leather surface in the plants were collected during active working hours. Microbiological contamination of the air was determined using an MAS-100 Eco Air Sampler (Merck, Germany). Samples of 501 and $100 \mathrm{l}$ of air, with flow rate: $100 \mathrm{l} / \mathrm{min}$, were taken directly onto MEA (Malt Extract Agar, Merck, Germany) with chloramphenicol (0.1\%) for determination of the total number of fungi (including hydrophilic and xerophilic fungi), and onto a TSA medium (Tryptic Soy Agar, Merck, Germany) with nystatin (0.2\%) for the determination of the total number of bacteria. Air samples were taken in 2 repetitions on each medium in 3 places in each room.

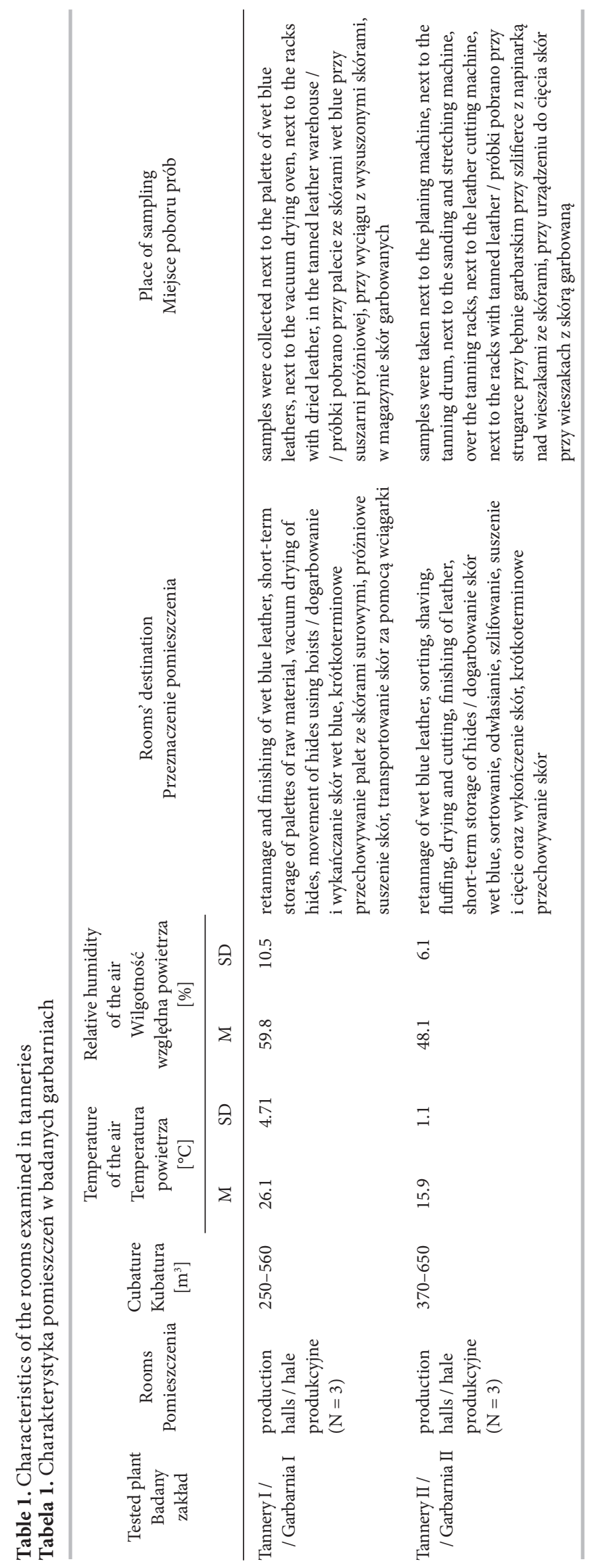




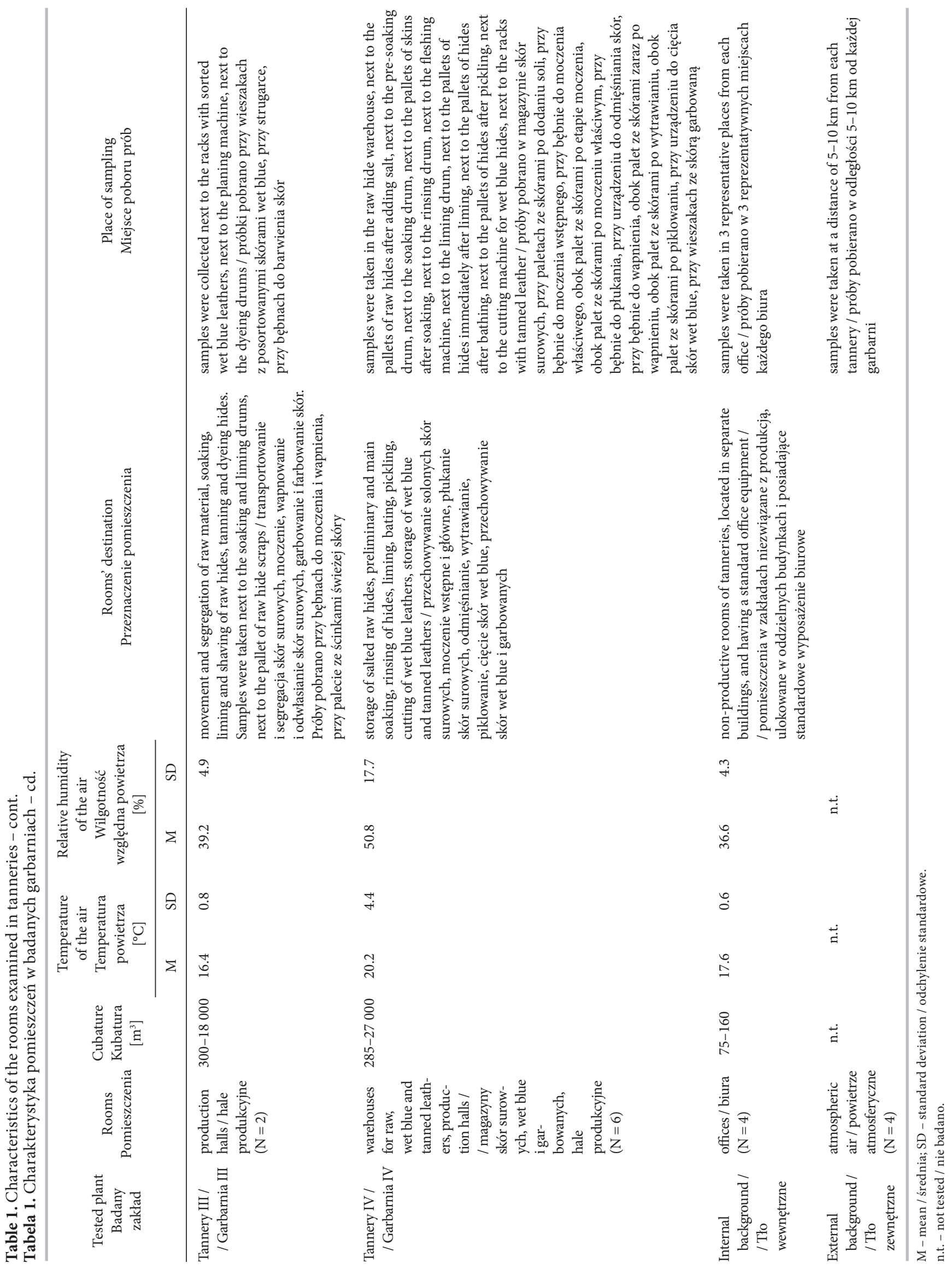


For the analysis of the size distribution of viable bioaerosols, a six-stage Andersen sampler (model WES-710, Westech Instruments, UK) was used. The use of this instrument made it possible to divide the bioaerosols into 6 fractions, in accordance with their aerodynamic diameters, as follows: $\geq 7.0 \mu \mathrm{m}$ (1st stage), 7.0-4.7 $\mu \mathrm{m}$ (2nd), 4.7-3.3 $\mu \mathrm{m}$ (3rd), 3.3-2.1 $\mu \mathrm{m}$ (4th), 2.1-1.1 $\mu \mathrm{m}$ (5th) and 1.1-0.65 $\mu \mathrm{m}$ (6th). The air was sampled with a vacuum pump at a constant $28.31 / \mathrm{min}$ flow rate. Samples were taken over $5 \mathrm{~min}$ (141.5 l of air) onto MEA with chloramphenicol (0.1\%) (fungi) or TSA medium with nystatin $(0.2 \%)$ (bacteria) in 3 repetitions on each medium in the production hall in Tannery I.

The materials processed in tanneries were also analyzed for microbiological content. The names of leather have been adapted from Thanikaivelan et al. (2004) (3):

- hide - skin of a large animal, such as cow or buffalo, leather - a general term for hide or skin with its original fibrous structure more or less intact, and that has been treated so as to be imputrecible, the hair or wool might or might not have been removed, wet blue - chrome-tanned leather in wet condition.

Samples from leathers were taken using RODAC Envirocheck ${ }^{\circledR}$ plates (Replicate Organism Detection And Counting, Merck, Germany) with TSA medium for bacteria and with Sabouraud medium (Merck, Germany) for fungi. For the analysis of the microbial contamination of hides, a traditional swab method was applied, using saline solution $(0.85 \% \mathrm{NaCl})$, swabs and metal frames of surface area $25 \mathrm{~cm}^{2}$ and media: MEA with chloramphenicol $(0.1 \%)$ (fungi) or TSA medium with nystatin $(0.2 \%)$ (bacteria). Samples were taken from 3 surfaces on each medium.

The media samples from the air and leather materials were incubated at $30 \pm 2^{\circ} \mathrm{C}$ for $48 \mathrm{~h}$ (bacteria) or at $27 \pm 2^{\circ} \mathrm{C}$ for $5-7$ days (fungi). After incubation, colonies were counted, and the results were expressed in CFU $/ \mathrm{m}^{3}$ air, CFU $/ 100 \mathrm{~cm}^{2}$ materials. The final result was the arithmetic mean of all of the repetitions.

\section{Identification of microorganisms}

The pure cultures of bacteria and yeast were characterized macroscopically, and then, selected diagnostic features were tested: Gram-staining, catalase test and oxidase test (Microbiologie Bactident Oxydase, Merck, Germany). For isolates of bacteria whose frequency of occurrence was greater than 25\%, API tests were performed (BioMérieux, France): API $50 \mathrm{CH}$, API STAPH and API $20 \mathrm{NE}$, for yeasts, diagnostics was performed using the API C AUX test. Bacteria identi- fied as indicators of microbiological contamination at workplaces in tanneries were determined according to the procedure described below, underwent the genetic identification based on the nucleotide sequence of gene $16 \mathrm{~S}$ rRNA (19).

Identification of all of the isolated filamentous fungi was performed basing on macroscopic and microscopic observations after culture on CYA medium (Difco, USA) and YES medium (Yeast Extract with Supplements), with the use of a taxonomic method (17-23).

Identification of moulds and yeast which were specified as the indicators of microbial contamination at workplaces was performed basing on the ITS $1 / 2 \mathrm{se}$ quence of the rDNA region (24). Genomic DNAs of indicators strains were extracted using the described method (25). The resulting nucleotide sequences of the studied microorganisms were analysed and compared with the sequences published in the National Center for Biotechnology Information (NCBI) database, using the BLASTN 2.2.27+ program (26). The sequences obtained for microorganisms were deposited in the NCBI GenBank database.

\section{Selection of indicators of microbiological contamination at workplaces}

In order to determine the indicators of microbiological contamination at workplaces in tanneries, protocols or characteristics were established according to Skóra et al. (2012) (27) and modified (frequency of strains isolation, source of isolation and harmfulness to human health) as given in Table 2. A scale of evaluation was also developed for identifying indicators of microbiological contamination at workplaces as given in Table 3.

\section{Mathematical calculations}

The frequency of occurrence of a species $(f)$ was calculated by dividing the number of samples in which the strain occurred and the total number of samples.

Statistical analyses were performed using STATISTICA 6.0 software (Statsoft, USA). The obtained results of microbiological contamination of the air and leathers in tanneries with various production profile were evaluated using one-way Analysis of Variance (ANOVA) at the significance level 0.05. When statistical difference was detected $(\mathrm{p}<0.05)$, means were compared by the post-hoc Tukey's test at significance level 0.05 .

Linear regression analysis was used to determine the effect of air humidity and air temperature on microbiological contamination of the air in tested tanneries. 


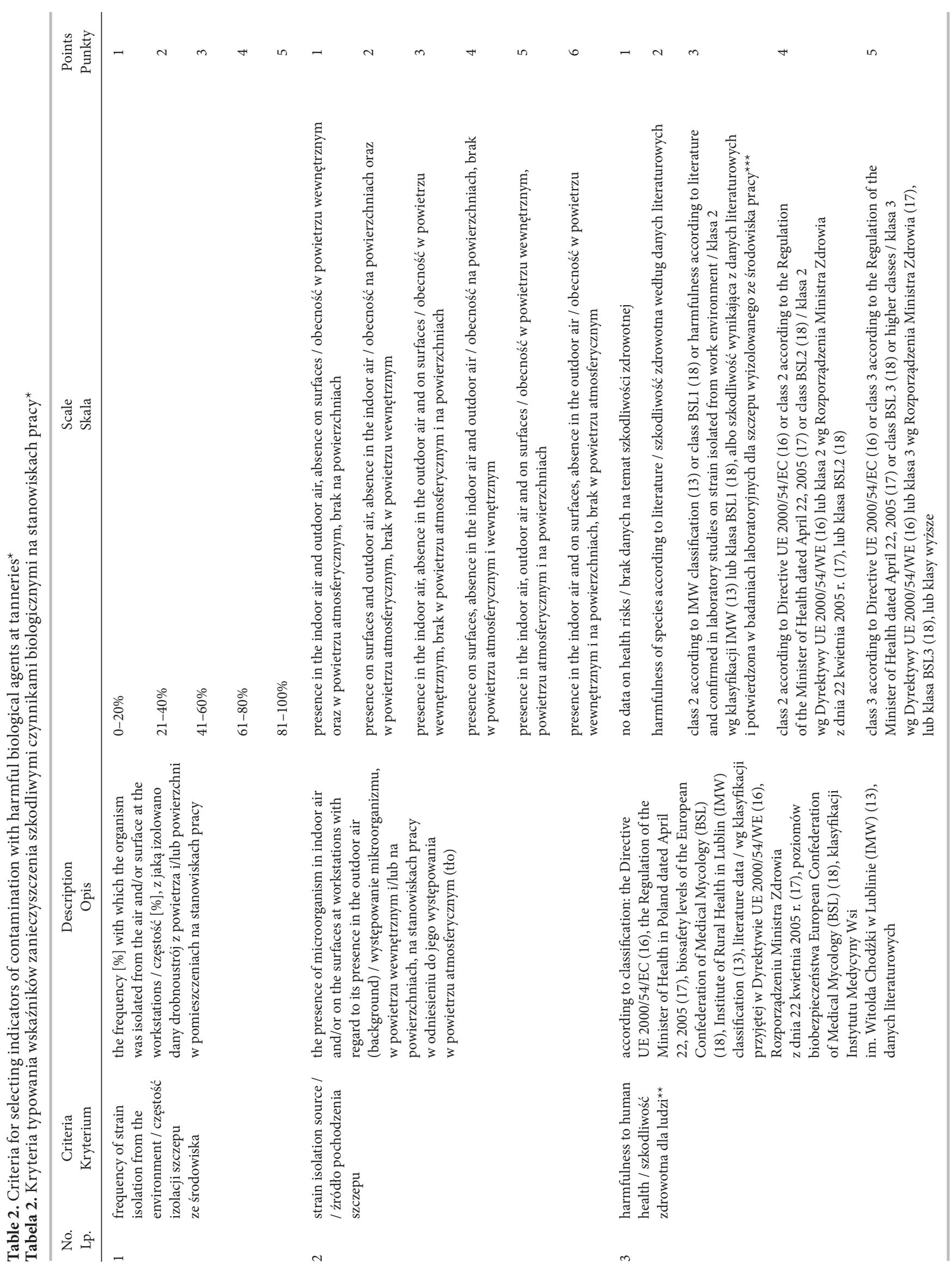




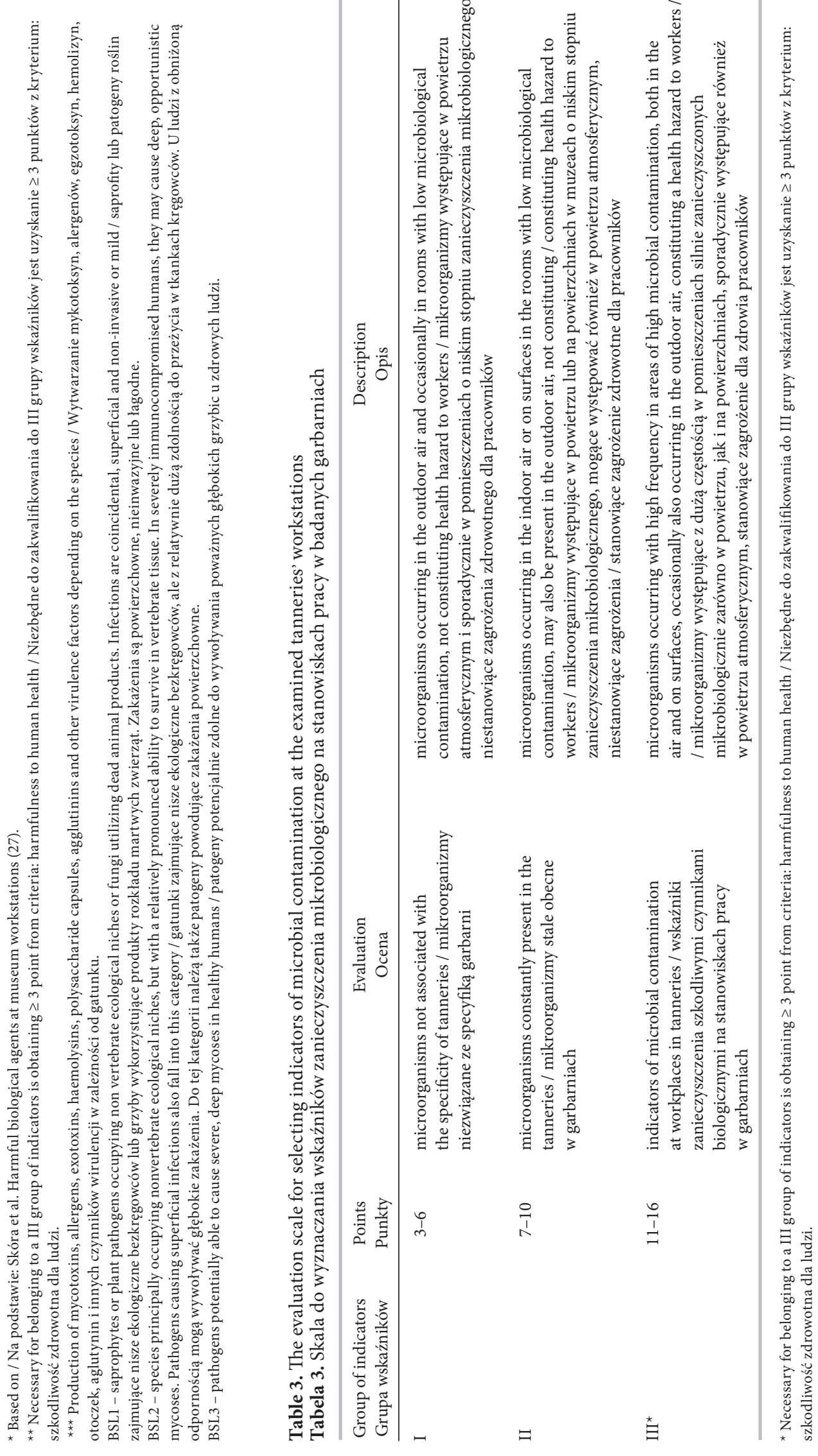




\section{RESULTS}

The number of microorganisms in the air of the tannery rooms ranged between $1.2 \times 10^{3}$ and $3.7 \times$ $\times 10^{3} \mathrm{CFU} / \mathrm{m}^{3}$. The number of bacteria in the tanneries producing chrome-tanned leather, the so-called wet blue (Tanneries I and II) was in the range from $5.1 \times 10^{2}$ to $6.1 \times 10^{2} \mathrm{CFU} / \mathrm{m}^{3}$, while in Tanneries III and IV, where leather production begun from the raw materials stage, it was higher, and reached $2.3 \times 10^{3}$ to $3.3 \times$ $\times 10^{3} \mathrm{CFU} / \mathrm{m}^{3}(\mathrm{p}<0.05)$.

Contamination with filamentous fungi in the air of the tanneries remained at a lower level, reaching $3.1 \times 10^{2}-1.4 \times 10^{3} \mathrm{CFU} / \mathrm{m}^{3}$ (Table 4 ).

The prevalence of bacteria in the air was reported in 3 out of 4 tested plants $(51-92 \%$ of all of the isolated microorganisms). The number of microorganisms detected on leathers ranged from $7.6 \times 10^{1}$ to $5.5 \times 10^{5} \mathrm{CFU} / 100 \mathrm{~cm}^{2}$. On the surface of raw hides, the number of bacteria was at the level of $5.5 \times 10^{5}$ to $1.2 \times 10^{6} \mathrm{CFU} / 100 \mathrm{~cm}^{2}$, and it was lower on wet blue leathers by about 4 orders of magnitude on the logarithmic scale (from $7.6 \times 10^{1}$ to $5.9 \times 10^{2} \mathrm{CFU} / 100 \mathrm{~cm}^{2}$ ). Bacteria constituted $60-100 \%$ of the total number of microorganisms isolated from test leathers (Table 5).

A qualitative analysis revealed the presence of 80 strains isolated in the tanneries, the highest species diversity was found for filamentous fungi (46 isolates), bacteria (25), and the lowest for yeasts (9).

Bacteria most frequently isolated from the air of the tanneries belong to the genera: Bacillus, Brevibacillus, Brevundimonas, Corynebacterium, Kocuria, Micrococcus, Staphylococcus. Bacteria from the genera of Micrococcus, Staphylococcus, and Pseudomonas were the most common bacteria species on leather surfaces (Table 6).

Moulds included Cladosporium, and Penicillium, and as for yeasts, Cryptococcus spp. were most frequently isolated from the leather processing plants. The leather surface was most often inhabited by Penicillium, Cryptococcus, Kodamaea and Pichia fungi (Table 6).

Basing on the developed criteria, taking into account the prevalence, source of isolation and health hazard, 11 species of indicator microorganisms for the tanneries were determined (risk group 3 was confirmed in the literature or by laboratory tests conducted by the authors in previous studies): B. pumilus, B. subtilis, B. cereus, Corynebacterium lubricantis, C. cladosporioides, Penicillium commune, P. echinulatum, P. chrysogenum, P. crustosum, Candida parapsilosis and Cryptococcus albidus (Table 6). The analysis of viable

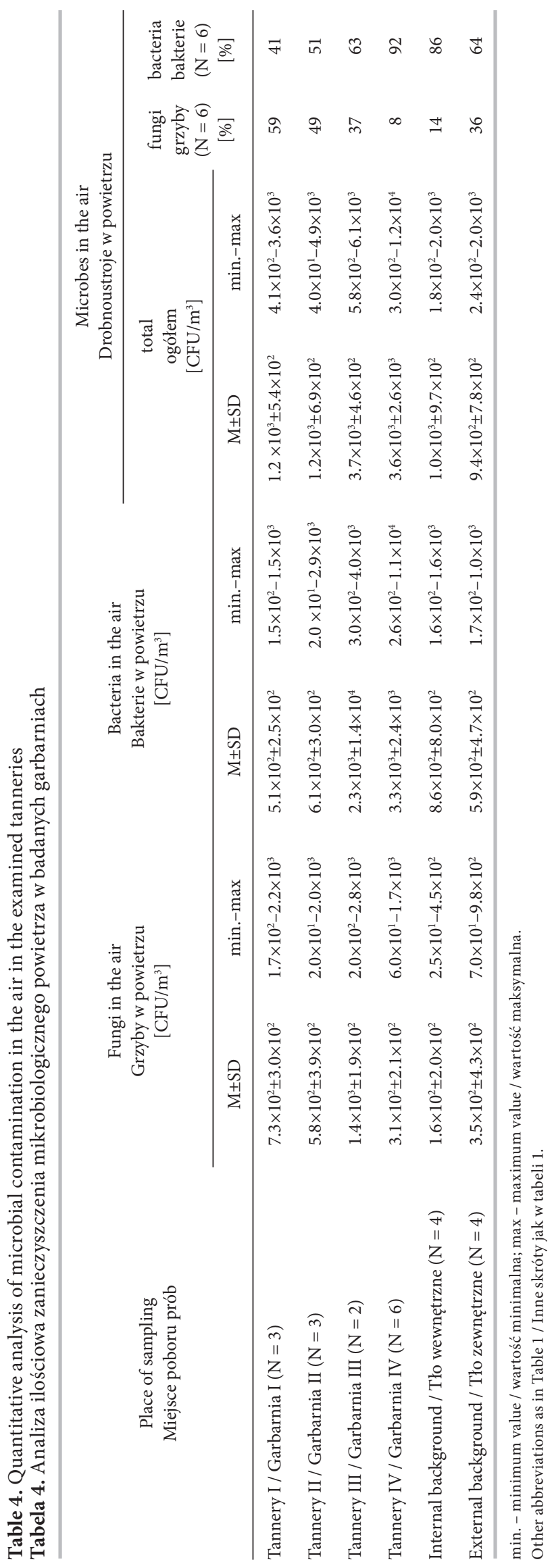




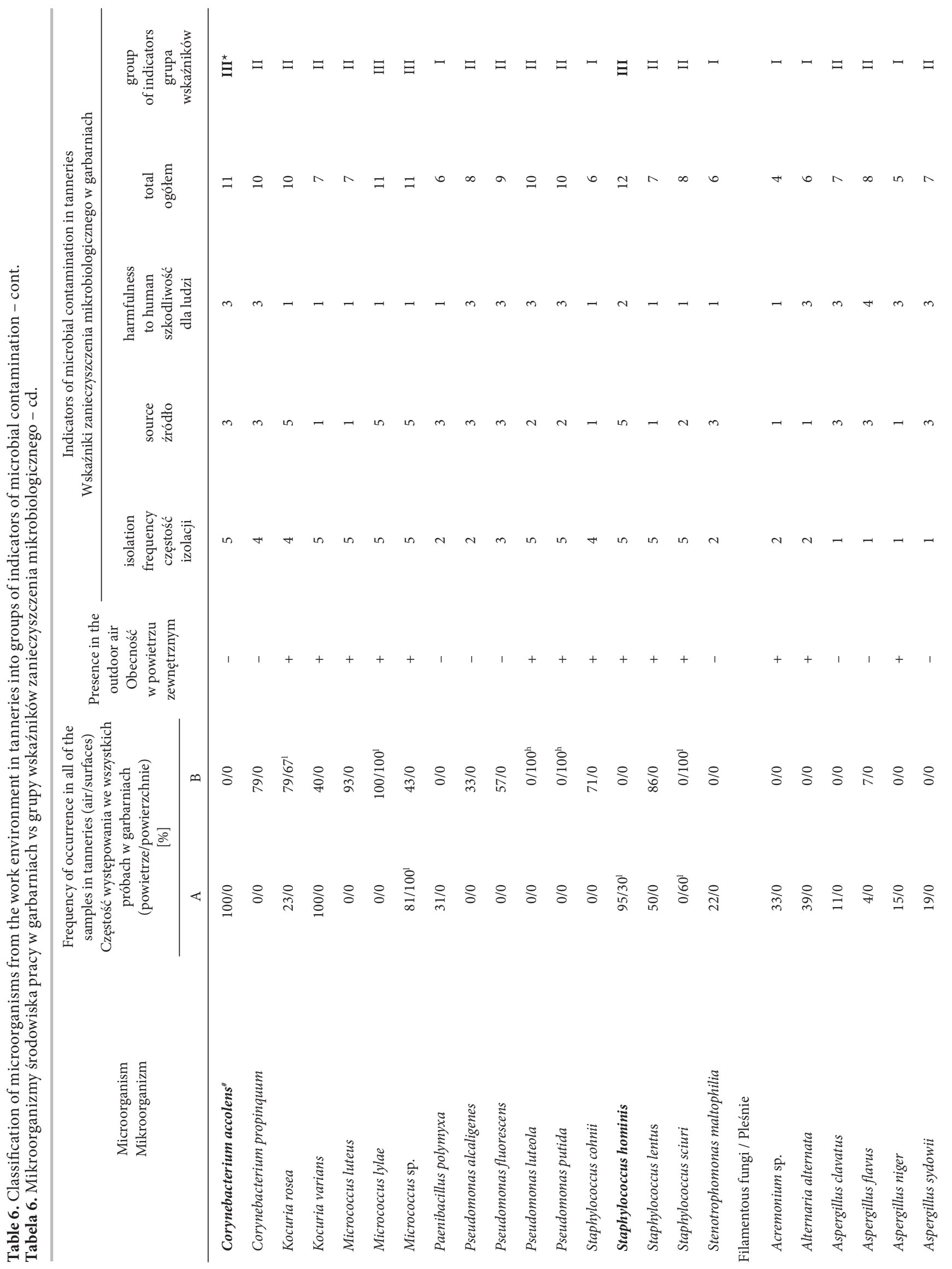




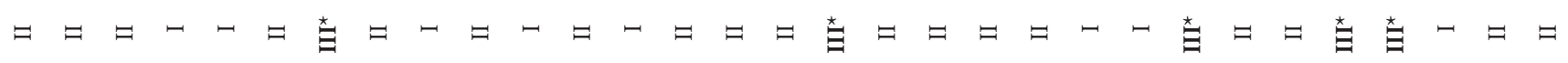

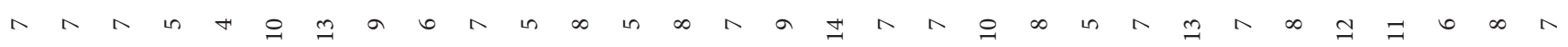

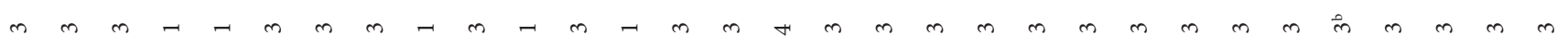

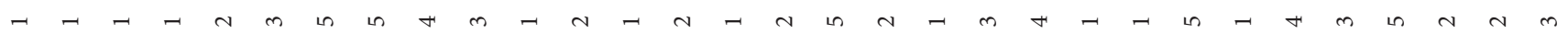

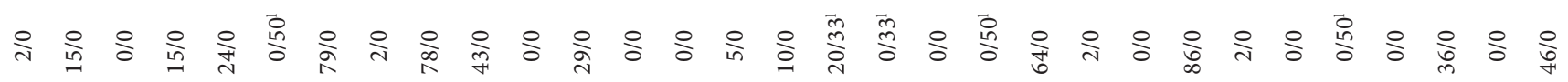

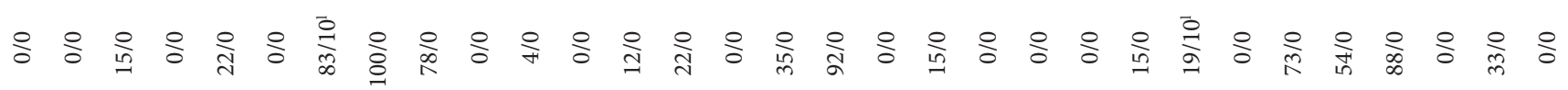

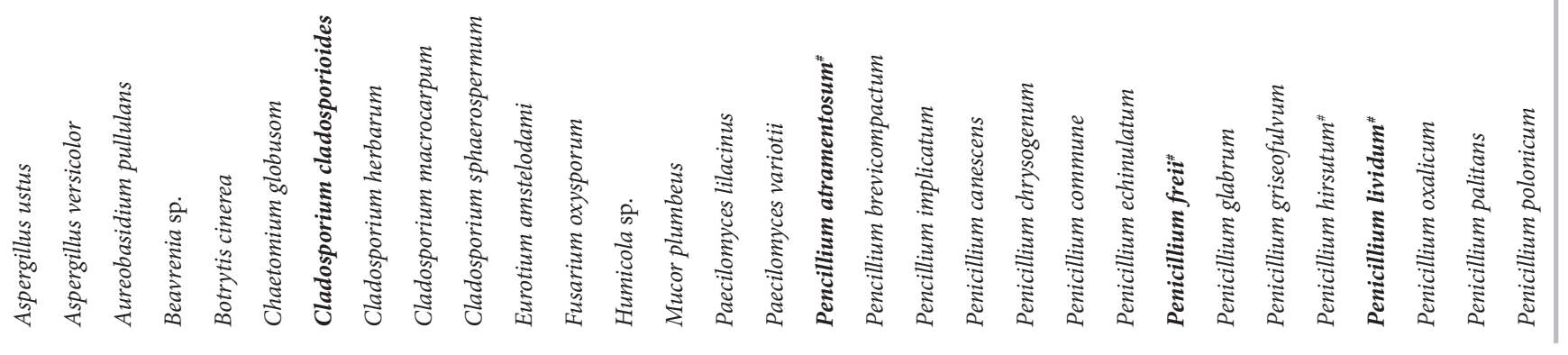




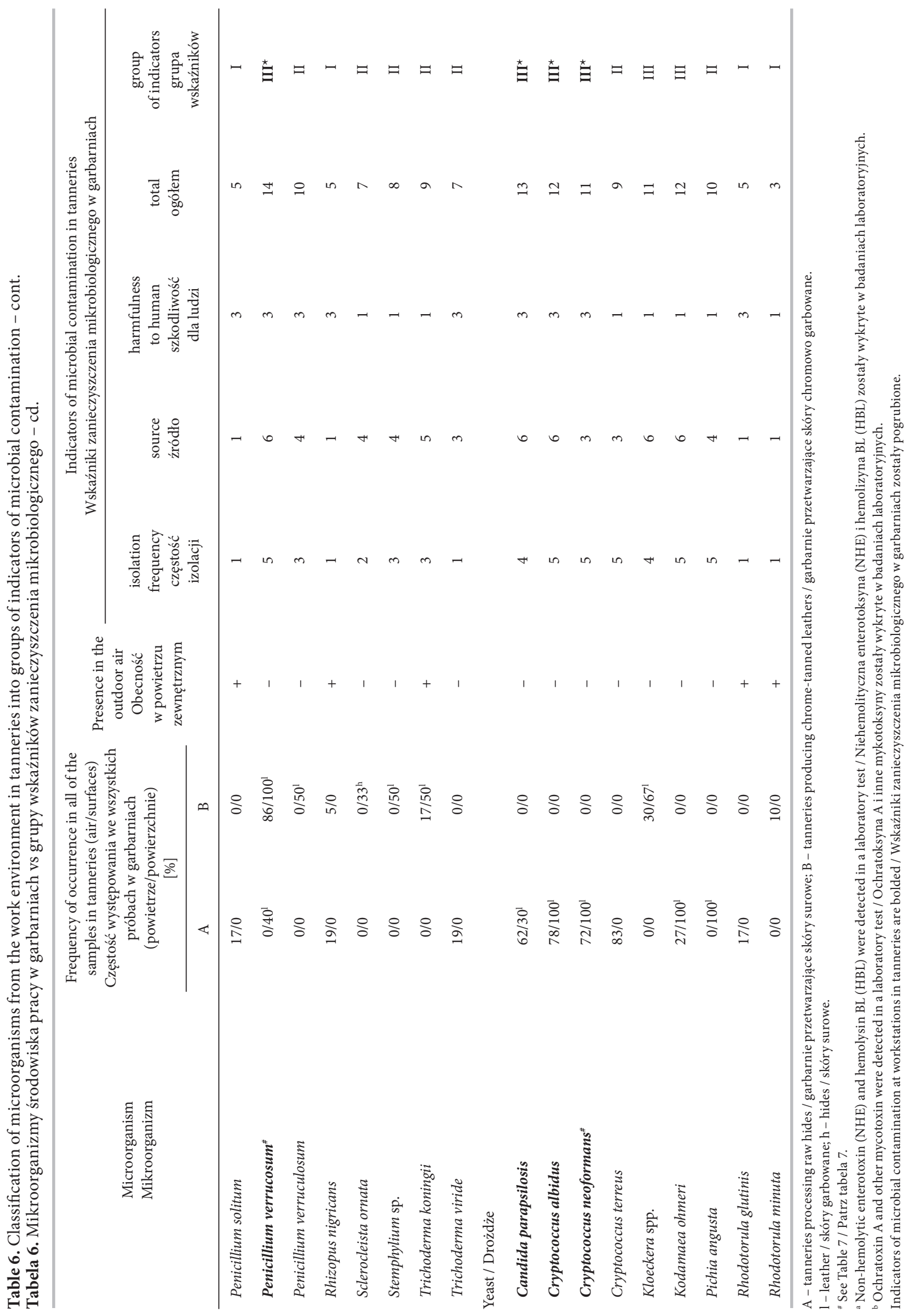


Table 7. Genetic analysis of indicators of harmful biological agents contamination in the examined tanneries Tabela 7. Analiza genetyczna wskaźników zanieczyszczenia szkodliwymi czynnikami biologicznymi w badanych garbarniach

\begin{tabular}{|c|c|c|c|c|}
\hline \multirow[t]{2}{*}{$\begin{array}{l}\text { Microorganisms } \\
\text { Mikroorganizmy }\end{array}$} & \multirow{2}{*}{$\begin{array}{c}\text { Identification } \\
\text { by conventional methods* } \\
\text { Identyfikacja } \\
\text { konwencjonalnymi metodami* }\end{array}$} & \multirow{2}{*}{$\begin{array}{l}\text { Identification } \\
\text { by genetic methods } \\
\text { Identyfikacja } \\
\text { metodami genetycznymi }\end{array}$} & \multicolumn{2}{|c|}{$\begin{array}{c}\text { Similarity of nucleotide sequences } \\
\text { to the compared strains } \\
\text { Podobieństwo sekwencji nukleotydowych } \\
\text { do porównywanych szczepów }\end{array}$} \\
\hline & & & $\begin{array}{l}\text { strain } \\
\text { szczep }\end{array}$ & $\%$ \\
\hline \multirow[t]{3}{*}{ Bacteria / Bakterie } & Bacillus pumilus & Bacillus pumilus & B. pumilus ATCC 7061 & 99 \\
\hline & Bacillus cereus & Bacillus cereus & B. cereus CMCC 63305 & 99 \\
\hline & Corynebacterium accolens & Corynebacterium lubricantis & C. lubricantis KSS-3Se & 100 \\
\hline \multirow[t]{4}{*}{ Fungi / Pleśnie } & Cladosporium cladosporioides & Cladosporium cladosporioides & C. cladosporioides ATCC 11275 & 100 \\
\hline & Pencillium atramentosum & Penicillium echinulatum & P. echinulatum FRR 1151 & 99 \\
\hline & Penicillium lividum & Penicillium commune & P. commune CBS 311.48 & 100 \\
\hline & Penicillium verrucosum & Penicillium crustosum & P. crustosum ATCC 90174 & 99 \\
\hline \multirow[t]{3}{*}{ Yeast / Drożdże } & Candida parapsilosis & Candida parapsilosis & C. parapsilosis ATCC 22019 & 99 \\
\hline & Cryptococcus albidus & Cryptococcus albidus & C. albidus CBS 969 & 99 \\
\hline & Cryptococcus neoformans & Rhodotorula glutinis & R. glutinis LEMI 150 & 99 \\
\hline
\end{tabular}

bioaerosol particle size distribution in the air of Tannery I demonstrated that its working environment was dominated by small particle sizes of 1.1-2.1 $\mu \mathrm{m}$. Both bacterial and fungal bioaerosol particles were the majority of all (24-37\%).
In the case of bacterial particles, a fraction of an aerodynamic diameter of $2.1-3.3 \mu \mathrm{m}$ (17-23\%) was also significant. The smallest share in the air of up to $10 \%$ was observed for bacterial particle size of $0.65-1.1 \mu \mathrm{m}$ (Figure 1). Percentages of individual bacterial bioaero-

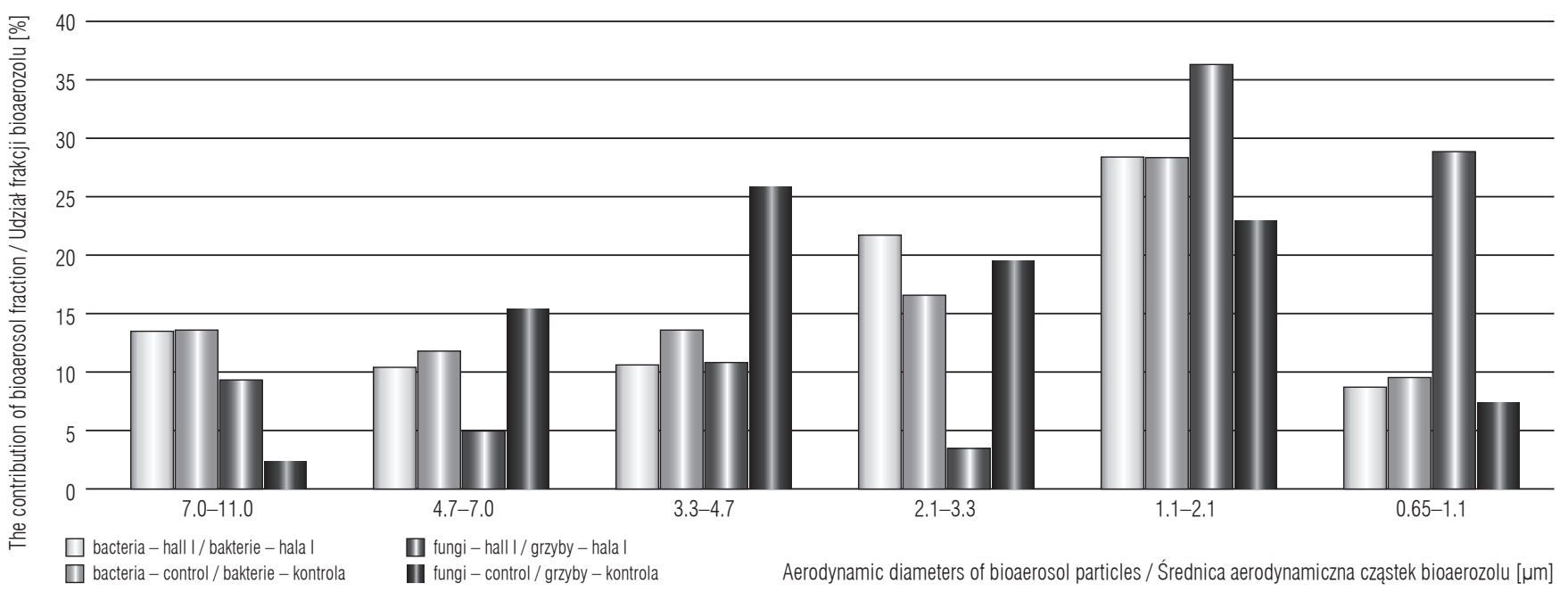

Fig. 1. The contribution of bioaerosol fraction of bioaerosol at workstations in tannery I

Ryc. 1. Rozkład frakcji bioaerozolu w bioaerozolu stanowisk pracy w garbarni I 
sol fractions were similar in the production room and in the control sample (outdoor air). The fungal bioaerosol particle distribution was different for the indoor air of the tanneries and in the atmospheric air. Control samples were dominated by fractions of particles with sizes ranging from 1.1 to $4.7 \mu \mathrm{m}$. The smallest particles with diameters of $0.65-1.1 \mu \mathrm{m}$ and $1.1-2.1 \mu \mathrm{m}$ were dominant in the production air, constituting $24-37 \%$ of the total fungal bioaerosol. Also, a higher percentage of large particles $(7.0-11.0 \mu \mathrm{m})$ in the production room was observed with respect to the control group.

\section{DISCUSSION}

Microclimate conditions prevailing in the working environment of tanneries (low temperature: $13-26^{\circ} \mathrm{C}$ and high humidity of the air: $40-90 \%$ ) are conductive to the growth of microorganisms.

The microbial contamination of the air in tanneries, depending on humidity and temperature of the air in both types of tanneries (producing hides and chrometanned leathers) were described with linear regression equations (Table 8). The regression analysis of the correlation between humidity and temperature in the tanneries and microbial contamination of air gave the determination coefficients in the range of 0.6013 to 0.9193 , indicating the significant influence of air humidity and temperature on the total number of microbes in the analysed air samples. The designated Pearson correlation coefficient for the examined correlations showed a positive value in the range of 0.78 to 0.96 , therefore, it can be concluded that with the increase of humidity and the temperature of the air the total number of microbes increases.

These studies demonstrated that microbial contamination of the air in the tanneries varied and depended on the characteristics of the plant and the used raw materials. The tanneries which processed raw hides and conducted a complete technological process involving advanced stages were characterized by about tenfold higher bacterial air contamination $(\mathrm{p}<0.05)$, while the microbial contamination of leather surfaces was 10000 times higher there than in the wet blue tanneries $(\mathrm{p}<0.05)$.

One-way analysis of variance with post-hoc Tukey's test confirmed the significant influence of tanneries profile production on microbiological contamination of the surfaces of hides and leathers as well as the air samples (expressed as the total number of microorganisms).

The maximum levels of air pollution reported in the tanneries implementing a full technological process (bacteria: $4.0 \times 10^{3}-1.1 \times 10^{4} \mathrm{CFU} / \mathrm{m}^{3}$, fungi: $1.7 \times 10^{3}-2.8 \times 10^{4} \mathrm{CFU} / \mathrm{m}^{3}$ ) indicate high inhalation exposure to biological agents. This confirms the status of the control air (outdoor air) which, due to the number of microorganisms, in accordance with PN-89/Z-04111/02 and PN-89/Z-04111/03 $(28,29)$, was clean air (less than $1.0 \times 10^{3} \mathrm{CFU} / \mathrm{m}^{3}$ of bacteria and less than $3.0 \times 10^{3} \mathrm{CFU} / \mathrm{m}^{3}$ of fungi) (Table 4) $(\mathrm{p}<0.05)$. These results clearly show that the level of pollution in plant premises is influenced by the used technological process. However, the number of microorganisms in the air of the test plants did not exceed the quantitative

Table 8. Regression coefficients defining the correlation between microbiological contamination of air in the examined tanneries and microclimate conditions (humidity and temperature)

Tabela 8. Współczynniki regresji opisujące zależność między liczbą drobnoustrojów w powietrzu w badanych garbarniach a warunkami mikroklimatu (wilgotność i temperatura)

\begin{tabular}{|c|c|c|c|c|c|}
\hline $\begin{array}{l}\text { Parameter } \\
\text { Parametr }\end{array}$ & \multicolumn{2}{|c|}{$\begin{array}{l}\text { Linear parameters of regression equations } \\
\text { Współczynniki liniowe równań regresji } \\
\qquad(\mathrm{y}=\mathrm{ax}+\mathrm{b})\end{array}$} & $\mathrm{R}^{2}$ & $\mathrm{r}$ & $\mathrm{p}$ \\
\hline \multicolumn{6}{|l|}{ Humidity } \\
\hline tanneries processing raw hides / garbarnie przetwarzające skóry surowe & 154.2 & -3484.9 & 0.9 & 0.9 & $<0.05$ \\
\hline \multicolumn{6}{|l|}{ Temperature } \\
\hline tanneries processing raw hides / garbarnie przetwarzające skóry surowe & 551.0 & -6825.0 & 0.9 & 0.9 & $<0.05$ \\
\hline $\begin{array}{l}\text { tanneries producing chrome-tanned leathers / garbarnie przetwarzające skóry } \\
\text { chromowo garbowane }\end{array}$ & 3237.6 & -53620.3 & 0.7 & 0.7 & $<0.05$ \\
\hline
\end{tabular}

$\mathrm{R}^{2}$ - determination coefficient / współczynnik determinacji; $\mathrm{r}$ - correlation coefficient / współczynnik korelacji. 
reference values established by the Polish Commission for Maximum Admissible Concentrations and Intensities for Agents Harmful to Health in the Working Environment (30) (for the total number of mesophilic bacteria of $1.0 \times 10^{5} \mathrm{CFU} / \mathrm{m}^{3}$, and the total number of fungi $5.0 \times 10^{4} \mathrm{CFU} / \mathrm{m}^{3}$ ).

The percentage of microorganisms in the air was different, depending on the type of the plant. In Tanneries III and IV, processing raw hides, bacteria frequencies ranged from 63 to $92 \%$, compared to the other test plants: $41-59 \%$. This fact is most likely the result of processing material (raw hides) being susceptible to bacterial attack and high humidity caused by the processes conducted in tanneries. The analysis of bacteria on the leather surface showed a significantly higher contamination of raw hides than wet blue leathers. Raw hides, during the study, were only contaminated with bacteria.

The results of the bioaerosol particle size distribution measurement in the tannery air are especially noteworthy. The bacterial particle size distribution in the indoor air was similar to that in the outdoor air. In the case of fungi, there were significant differences $(\mathrm{p}<0.05)$ between the production and control air. It was found that the smallest (fractions: $0.65-1.1 \mu \mathrm{m}$ and 1.1-2.1 $\mu \mathrm{m})$ and the largest test particles $(7.0-11.0 \mu \mathrm{m})$ were found dominant in the production hall. This phenomenon is likely to arise due to the grouping of fungi in units of dust created during production (large particles) or the lifting of single mould spores with the movement of air (small particles).

The analysis of fungal bioaerosol distribution in the tannery indicates that the dominant fractions of aerodynamic diameters of $0.65-1.1 \mu \mathrm{m}$ and $1.1-2.1 \mu \mathrm{m}$ (together accounting for 67\%) may penetrate the pulmonary alveolus of tanners, which may consequently lead to the occurrence of unspecific airways inflammation and allergic disorders (31). Moreover the exposure to the mould's $\beta$-D-glucan mays causes inflammation reactions in lymphocytes, affects interleukin-1 secretion via T-lymphocytes, stimulates tumour defence mechanisms, causes a decrease in the numbers of pulmonary macrophages and inhibits phagocytosis (32). Consequently, the effects of glucan can lead to fatigue, headaches and other neurological symptoms in exposed workers, especially in the municipal waste industry and in different branches of agriculture $(33,34)$.

Twelve species of microorganisms were selected as indicators for the working environment of the tanneries. They indicated a potential health hazard to workers and were associated with the specificity of raw mate- rial and the working conditions in the tanneries. They included 4 bacteria: B. pumilus, B. subtilis, B. cereus, Corynebacterium lubricantis, 5 moulds: C. cladosporioides, Penicillium commune, $P$. echinulatum, $P$. chrysogenum, P. crustosum and 2 species of yeasts: Candida parapsilosis and Cryptococcus albidus. Genetic identification of yeasts initially classified as Cryptococcus neoformans showed that they belonged to the species of Rhodotorula glutinis.

No data is available on the adverse effects of this yeast to human health, which is why it is not presented as an indicator species. The genetic analysis also indicated differences in the taxonomic classification of 1 bacteria species from genus Corynebacterium and even 5 mould species belonging to the genus of Penicillium selected as indicators of microbial contamination in the tanneries. The usefulness of molecular biology methods in the diagnostics of moulds isolated from the air has been proven $(35,36)$.

Microorganisms designated as indicators of contamination with harmful biological agents in the tanneries are described in the literature as potentially pathogenic and dangerous to human health. The indicators in cluded up to 3 species of the genus Bacillus (B. subtilis, $B$. cereus, B. pumilus). The presence of these bacteria had been previously identified as typical for leather (4) and air microflora in tanneries (37). B. subtilis has allergenic effects particularly burdensome for the employees of the biotechnology industry (production of enzymatic proteins) (38). This species is classified by the Regulation of the Minister of Health, 2005 (Journal of Laws of 2005, No. 81, item 716, as amended and the Journal of Laws 2008, No. 48, item 288) as a risk group 2 (17).

Another bacterium of this type, B. cereus, may exhibit toxic effects (it produces enterotoxins causing food poisoning), and infectious diseases - pneumonia, in exposed tanners through contact with food, airborne dust and airborne droplets (39). The ability to induce a-haemolysis and toxicity was detected for the strain isolated from the tanneries - laboratory tests showed a nonhemolytic enterotoxin (NHE) and hemolysin BL (HBL) (unpublished data). Bacillus pumilus is also considered an etiologic agent of food poisoning, while in the case of direct contact, it can cause skin infections (40).

Corynebacterium lubricantis bacteria are responsible for opportunistic infections in humans - Directive 2000/54/EC classifies all of the species of this genus as risk group 2 (16).

Designated as an indicator of microbial contamination in the tanneries, C. cladosporioides is a common 
cause of allergic diseases in people exposed to the inhalation of bioaerosol in which they occur. C. cladosporioides allergens have been characterized in terms of structure and biological function by the World Health Organization and the International Union of Immunological Societies (WHO/IUIS), the Allergen Nomenclature Sub-committee (41).

Dutkiewicz et al. (2007) (13) indicate that occupational hazard caused by the moulds of the genus Penicillium may lead to alveolitis allergica, bronchial asthma, allergic rhinitis and discomfort caused by toxicity in exposed workers. These moulds are known producers of citrinin, citreoviridin, cyclopiazonic acid, secalonic acid D, patulin, rubratoxin A and B, viridiatin (21). Laboratory tests showed that Penicillium chrysogenum moulds designated as the indicators of contamination with harmful biological agents in the tanneries produce a number of toxins, including ochratoxin A, aurofusarin, brevianamid F, brevicompanine B, chrysophanol, emodin, meleagrin, roquefortine $\mathrm{C}$ or secalonic acid D (author's unpublished data).

The yeasts recognized as indicators of contamination with harmful biological agents in the tanneries included the species of $C$. albidus and C. parapsilosis. C. albidus may show invasive activity, it was isolated from the samples of human material, taken especially from hospitalized patients belonging to the so-called high risk groups (reduced immunity), C. parapsilosis has the ability to cause opportunistic fungal infections. These are usually the diseases of the mucous membranes, skin, internal organs and systemic diseases and sepsis (42).

The analysis of the air and leather surfaces in the tanneries has shown that the designated indicators of contamination with harmful biological agents are associated with the specific working environment. Their primary source, as indicated by the literature, may be animal material, soil and dust. The studies showed that the prevalence of the indicator isolates in the production space was high and reached $19-100 \%$ in the air and $10-100 \%$ on leathers, depending on the isolates.

\section{CONCLUSION}

The assessment of microbial contamination in the working environment of the tanneries showed increased numbers of bacteria and fungi in the air of production spaces in relation to the outdoor air. The level of microbial contamination is influenced by a technological process and the processed material. The studies conducted in the 2 types of tanneries demonstrated that those processing raw hides had a higher contamination of the air and leather surface ( 1 and 4 orders of magnitude on the logarithmic scale) compared to the wet blue leather manufacturers. Bacteria were dominant among the microorganisms isolated in the tanneries. The bioaerosol particle size distribution in the production space of the tanneries indicates health risks arising from the possibility of inhaling fungal particles of sizes $0.65-1.1 \mu \mathrm{m}$ and $1.1-2.1 \mu \mathrm{m}$, which may adversely affect the respiratory system of workers.

Basing on the prevalence, the source of isolation and health risk to people, 11 indicator microbial species were determined for the tanneries: B. pumilus, B. subtilis, B. cereus, C. lubricantis, C. cladosporioides, P. commune, $P$. echinulatum, $P$. chrysogenum, $P$. crustosum, C. parapsilosis, $C$. albidus. It has been shown that these are the species described in the literature as potentially pathogenic and associated with the specific technological processes in tanneries.

Although there were no exceedances of the permitted number of microorganisms recommended by the Interdepartmental Commission for Maximum Admissible Concentrations and Intensities for Agents Harmful to Health in the Working Environment, the presence of microorganisms that could compromise the health of workers in the working environment was observed. Personal protection equipment should be used in tanneries, for instance, FFP3 half-masks that will protect workers from inhaling organic dust, chemicals and bioaerosol. Bioactive half-masks showing bacteriostatic and biocidal effects on microorganisms may also be suitable. It is recommended to develop guidelines for the control of harmful biological agents and methods for removing biological threats for this type of plants.

\section{REFERENCES}

1. European Commission Eurostat. Statistic data of European Commission, Eurostat U.S.A. [cited 2013 Oct 10]. Available from: http://epp.eurostat.ec.europa.eu/portal/ page/portal/statistics/themes.

2. Cassano A, Molinari R, Romano M, Drioli E. Treatment of aqueous effluents of the leather industry by membrane processes: A review. J Memb Sci. 2001;181(1):111-26, http://dx.doi.org/10.1016/S0376-7388(00)00399-9.

3. Thanikaivelan P, Rao JR, Nair BU, Ramasami T. Progress and recent trends in biotechnological methods for leather processing. Trends Biotechnol. 2004;22(4):181-8, http://dx.doi.org/10.1016/j.tibtech.2004.02.008. 
4. Orlita A. Microbial biodeterioration of leather and its control: A review. Int Biodeterior Biodegrad. 2004;53(3): 157-63, http://dx.doi.org/10.1016/S0964-8305(03)00089-1.

5. Pietrzykowski W. [Defects and biological damage of hides]. Przegl Skorzany. 1988;153:5-8. Polish.

6. Bailey D, Birbir M. The impact of halophilic organisms on the grain quality of brine cured hides. J Am Leather Chem Assoc. 1996;91(2):47-51.

7. Rother $\mathrm{H}$. Microorganisms the scourge of the leather industry. World Leather. 1995;5:48-50.

8. Falkiewicz-Dulik M. [Leather, leather products and parchment]. In: Zyska B, Żakowska Z, editors. [Materials microbiology]. Łódź: Lodz University of Technology; 2005. p. 187-226. Polish.

9. Lindner W, Neuber $H$. Preservation in the tannery. Int Biodeterior. 1990;26(2-4):195-203, http://dx.doi.org/ 10.1016/0265-3036(90)90059-G.

10. Kowalik R. [Microbial degradation of technical materials]. Postepy Mikrobiol. 1969;1:105-25. Polish.

11. Zapletal P. [Impact of damage to cattle hides on their commercial value after the tanning]. Przegl Skorzany. 1997;10:391. Polish.

12. Orlita A. Microbial biodeterioration of leather and its control. Proceedings of the II International Scientific Conference Microbial Biodegradation and Biodeterioration of Technical Materials; 2001 May 30-31; Łódź, Poland. Łódź: Lodz University of Technology; 2001. p. 41-5.

13. Dutkiewicz J, Śpiewak R, Jabłoński L, Szymańska J. [Biological occupational risk factors. Classification, exposed occupational groups, measurement, prevention]. Lublin: Ad Punctum; 2007. Polish.

14. Ory FG, Rahman FU, Katagade V, Shukla A, Burdorf A. Respiratory disorders, skin complaints, and low-back trouble among tannery workers in Kanpur, India. Am Ind Hyg Assoc J. 1997;58(10):740-6, http://dx.doi.org/ 10.1080/15428119791012397.

15. Rastogi SK, Pandey A, Tripathi S. Occupational health risks among the workers employed in leather tanneries at Kanpur. Indian J Occup Environ Med. 2008;12(3):132-5, http://dx.doi.org/10.4103/0019-5278.44695.

16. Directive 2000/54/EC of the European Parliament and of the Council of 18 September 2000 on the protection of workers from risks related to exposure to biological agents at work. Off J Eur Communities. L. 262/21 (2000).

17. [Regulation of the Minister of Health dated 2005 April 22. Journal of Laws 2005, No. 81, item 716, as amended and Journal of Laws 2008, No. 48, item 288]. Polish.

18. Report of a Working Group on Hazardous Fungi of the European Confederation of Medical Mycology (ECMM). Risk assessment of fungi reported from humans and animals. Mycoses. 1996;39(11-12):407-17, http://dx.doi. org/10.1111/j.1439-0507.1996.tb00089.x.

19. Jensen MA, Webster JA, Straus N. Rapid identification of bacteria on the basis polymerase chain reaction - amplified ribosomal DNA spacer polymorphisms. Appl Environ Microbiol. 1993;59(4):945-52.

20. Bensch K, Groenewald JZ, Dijksterhuis J, StarinkWillemse M, Andersen B, Summerell BA, et al. Species and ecological diversity within the Cladosporium cladosporioides complex (Davidiellaceae, Capnodiales). Stud Mycol. 2010;67(1):1-94, http://dx.doi.org/10.3114/ sim.2010.67.01.

21. Frisvad JC, Samson RA. Polyphasic taxonomy of Penicillium subgenus Penicillium. A guide to identification of food and airborne terverticillate penicillia and their mycotoxins. Stud Mycol. 2004;49:1-174.

22. Klich MA. Identification of common Aspergillus species. Utrecht: Centraalbureau voor Schimmelcultures; 2002.

23. Pitt JI, Hocking AD. Fungi and food spoilage. North Ryde: Springer; 2009, http://dx.doi.org/10.1007/ 978-0-387-92207-2.

24. White TJ, Bruns T, Lee S, Taylor J. Amplification and direct sequencing of fungal ribosomal RNA genes for phylogenetic. In: Innis MA, Gelfand DH, Shinsky JJ, White TJ, editors. PCR protocols: A guide to methods and applications. San Diego: Academic Press; 1990. p. 315-22.

25. Stępień Ł, Koczyk G, Waśkiewicz A. Genetic and phenotypic variation of Fusarium proliferatum isolates from different host species. J Appl Genet. 2011;52:487-96, http://dx.doi.org/10.1007/s13353-011-0059-8.

26. Zhang Z, Schwartz S, Wagner L, Miller W. A greedy algorithm for aligning DNA sequences. J Comput Biol. 2000;7(1-2):203-14, http://dx.doi.org/10.1089/ 10665270050081478.

27. Skóra J, Zduniak K, Gutarowska B, Rembisz D. [Harmful biological agents at museum workposts]. Med Pr. 2012;63(2):153-65. Polish.

28. PN-Z-04111-02:1989. [Air purity protection. Microbial tests. Determination of the numer of bacteria in the atmospheric air (immission) with sampling by aspiration and sedimentation method]. Warszawa: Polski Komitet Normalizacji Miar i Jakości; 1989. Polish.

29. PN-Z-04111-03:1989. [Air purity protection. Microbial tests. Determination of the numer of filamentous fungi in the atmospheric air (immission) with sampling by aspiration and sedimentation method]. Warszawa: Polski Komitet Normalizacji Miar i Jakości: 1989. Polish.

30. Skowroń J, Górny R. [Harmful biological agents]. In: Augustyńska D, Pośniak M, editors. [The Interdepartmental Commission for Maximum Admissible Concen- 
trations and Intensities for Agents Harmful to Health in the Working Environment: limit values 2012]. Warszawa: Centralny Instytut Ochrony Pracy - Państwowy Instytut Badawczy; 2012. Polish.

31. Kulkarni P, Baron PA, Willeke K. Aerosol measurement: principles, techniques, and applications. New York: John Wiley and Sons Inc.; 2011, http://dx.doi.org/ 10.1002/9781118001684.

32. Rylander R, Persson K, Goto H, Yuasa K, Tanaka S. Airborne beta-1,3-glucan may be related to symptoms in sick buildings. Indoor Environ. 1992;1:263-7, http://dx.doi.org/10.1177/1420326X9200100502.

33. Šandula J, Kogan G, Kaćuráková M, Machová E. Microbial (1-3)- $\beta$-D-glucans, their preparation, physico-chemical characterization and immunomodulatory activity. Carbohydr Polym. 1999;38:247-53, http://dx.doi.org/10.1016/S0144-8617(98)00099-X.

34. Wouters IM, Spaan S, Douwes J, Doekes G, Heederik D. Overview of personal occupational exposure levels to inhalable dust, endotoxin, $\beta(1-3)$-glucan and fungal extracellular polysaccharides in the waste management chain. Ann Occup Hyg. 2006;50:39-53, http://dx.doi.org/10.1093/annhyg/mei047.

35. Davolos D, Pietrangeli B. DNA sequencing and phylogenetic analysis of allergen-encoding genes from airborne moulds and yeasts. Prevention Today. 2007;3(3):23-35.
36. Hung W-T, Su S-L, Shiu L-Y, Chang TT. Rapid identification of allergenic and pathogenic molds in environmental air by an oligonucleotide array. BMC Infect Dis. 2011;11:91-9, http://dx.doi.org/10.1186/1471-2334-11-91.

37. Gutarowska B, Piotrowska M. [Microbial contamination of the air on particular workplaces in tannery]. Ekol Tech. 2008;16(5):224-8. Polish.

38. Pepys J. Allergic asthma to Bacillus subtilis enzyme: A model for the effects of inhalable proteins. Am J Ind Med. 1992;21(4):587-93, http://dx.doi.org/10.1002/ajim. 4700210414.

39. McKillip JL. Prevalence and expression of enterotoxins in Bacillus cereus and other Bacillus spp. A literature review. Antonie Van Leeuwenhoek. 2000;77(4):393-9, http://dx.doi.org/10.1023/A:1002706906154.

40. Kayser FH, Bienz KA, Eckert JE, Zinkernagel RM. Medical Microbiology. Stutgard, New York: Thieme; 2005.

41. International Union of Immunological Societies Allergen Nomenclature Sub-committee. Database of World Health Organization and International Union of Immunological Societies [cited 2013 Oct 10]. Available from: http://www.allergen.org.

42. Trofa D, Gácser A, Nosanchuk JD. Candida parapsilosis. An emerging fungal pathogen. Clin Microbiol Rev. 2008;21(4):606-25, http://dx.doi.org/10.1128/ CMR.00013-08. 